\title{
ALGORITMA MODULAR UNTUK SISTEM PROSES DENGAN RECYCLE - KEADAAN TUNAK PADA PERANGKAT LUNAK BEBAS BIAYA LISENSI
}

\author{
Setia Budi Sasongko \\ Jurusan Teknik Kimia Fakultas Teknik UNDIP \\ Jl. Prof. Sudarto, SH, Tembalang-Semarang 50239; Telp.(024) 7460058 \\ E-mail: budisas@undip.ac.id
}

\begin{abstract}
Computer simulasion can be developed to comprehend a system process characteristic and can be used to train the operator of process. The first problem of programming is high price of the licence. Using the FOC (free of charge) software solve of the previous problem such as Scilab and Open Office which comparable with Matlab and Excel. The objectives of this article develop process system programming which has recycle system and user friendly programming. Modular algorithm programming is introduced to solve recycle process system. Graphical User Interface (GUI) also introduces to make user friendly programming. Execution of the program performs stable and correct results.
\end{abstract}

Key words : free of charge software, modular algorithm, open office-calc, recycle, scilab

\begin{abstract}
Abstrak
Simulasi komputer pada sistem proses dikembangkan sebagai bagian untuk memahami karakteristik dari sistem dan diharapkan dapat digunakan sebagai training untuk operator sistem proses. Permasalahan yang mendasar dalam mengembangkan simulasi sistem proses adalah perangkat lunak yang relatif mahal. Saat ini, masalah tersebut dapat diatasi dengan menggunakan perangkat lunak yang bersifat bebas biaya, dalam hal ini digunakan Scilab dan open Office Calc yang ekivalen dengan Matlab dan Excel. Pengembangan pemrograman dengan algoritma modular untuk sistem dengan recycle serta program yang bersifat user friendly merupakan tujuan dan sebagai bagian dari metodologi penyelesaian dari sistem proses. Eksekusi dari program beserta tahap penyelesaian menunjukkan hasil yang stabil dan cukup akurat.
\end{abstract}

Kata kunci : perangkat lunak gratis, algoritma modular, open office-calc, recycle, scilab

\section{PENDAHULUAN}

Salah satu tugas bidang enjinering kimia adalah merancang sistem proses. Perancangan merupakan suatu aktivitas yang cukup komplek dan bervariasi. Saat ini perancangan dengan menggunakan bantuan komputer atau perangkat lunak siap pakai sudah cukup banyak dan berkembang, seperti Aspen-Hysys, ChemCAD dan lain sebagainya. Dengan menggunakan perangkat lunak tersebut, proses analisis untuk suatu sistem akan berlangsung dengan cepat. Permasalahan yang ada dengan menggunakan perangkat lunak tersebut adalah dibutuhkan biaya yang relatif mahal. Selain itu, dengan menggunakan perangkat lunak siap pakai terkadang filosofi dari perancangan alat menjadi berkurang. Hal ini kurang menguntungkan khususnya dalam bidang pendidikan.

Oleh karenanya, artikel ini bertujuan untuk mengembangkan ide simulasi sistem proses yang sesuai dengan kebutuhan dari pengguna akhir (user friendly) dengan menggunakan perangkat lunak berlisensi bebas biaya (free of charge, FOC), yaitu Scilab dan open Office Calc (oO-Calc). Sebagai pembatas masalah pada artikel ini, hanya akan dibahas penyusunan sistem proses berdasarkan neraca bahan (massa) saja.

\section{Fundamental}

Menurut Biegler et al (1997) metoda penyelesaian dari simulasi untuk sistem proses khususnya untuk neraca massa dan energi dapat dibedakan menjadi dua cara, yaitu orientasi persamaan total (equation oriented) dan modular. Pada penyelesaian dengan metoda orientasi persamaan total, maka semua persamaan proses (neraca massa dan energi, unjuk kerja dari peralatan, karakteristik termodinamika, transport, kinetika dan 
hubungan persamaan yang lain) pada sistem yang ditinjau harus disusun secara keseluruhan kemudian diselesaikan secara simultan. Penyelesaian dengan metoda pertama, akan didapat persamaan dengan jumlah yang relatif besar dan banyak. Selain itu, penyelesaian dengan sistem berorientasi persamaan total tersebut bersifat spesifik, artinya dengan merubah sistem misalkan diagram alir proses, maka seluruh persamaan akan berubah. Sedangkan penyelesaian dengan metoda yang ke dua, yaitu sistem modular, penyelesaiannya dilakukan secara bertahap dimana tiap tahapan pada pemrograman disebut dengan modul atau dalam bahasa pemrograman sebagai sub-rutin atau bagian sub-program. Dengan demikian, pengguna akhir pada saat menyusun sistem proses, pada dasarnya merupakan penggabungan dari sub-program yang relatif kecil sehingga apabila ada kesalahan program penyelesaian atau pencarian kesalahan tersebut menjadi lebih mudah. Pengabungan dari modul-modul program pada artikel ini disebut dengan algoritma modular. Penyelesaian akan menjadi lebih rumit dan menarik, apabila dalam sistem proses terdapat aliran daur ulang (recycle).

Proses penyelesaian dari sistem proses secara umum, diawali dengan menentukan semua bahan yang ada dalam sistem proses baik bahan baku, produk antara, produk akhir maupun bahan inert. Dilanjutkan dengan mencari sifat-sifat kimia, fisika berdasarkan tinjauan kinetika maupun termodinamika. Kemudian menggambarkan diagram alir proses yang terdiri dari aliran bahan serta satuan operasi (unit operation) berupa reaktor, peralatan pemisahan, perubah ukuran bahan, perubah fase, perubah kondisi operasi, pengangkutan (pemindahan) bahan.

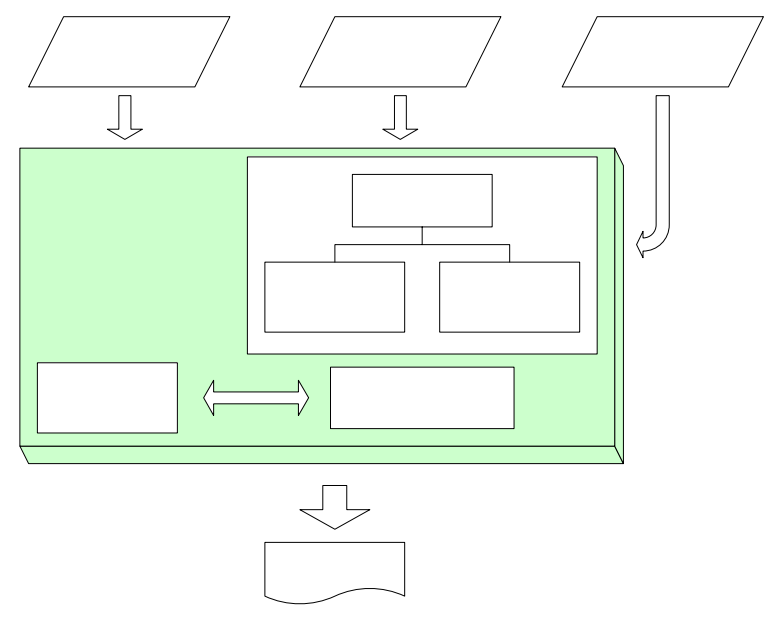

Gambar 1. Hubungan perangkat lunak dengan pengguna

Untuk mendapatkan hasil perhitungan lebih cepat dan akurat, maka dapat digunakan komputer sebagai alat bantu. Sifat-sifat dari bahan maupun perhitungan termodinamika dan kinetika bahan dapat disimpan dan dilakukan dengan bantuan komputer, demikian juga dengan sub rutin dari satuan operasi, urutan perhitungan berdasarkan diagram alir proses. Dengan demikian, hubungan antara pengguna akhir dengan komputasi serta hasil keluaran dari komputer sebagai bagian dari perangkat lunak, dapat dilihat pada Gambar 1.

Diagram alir proses (DAP) disusun berdasarkan simbol sebagaimana yang ditunjukkan Gambar 2.

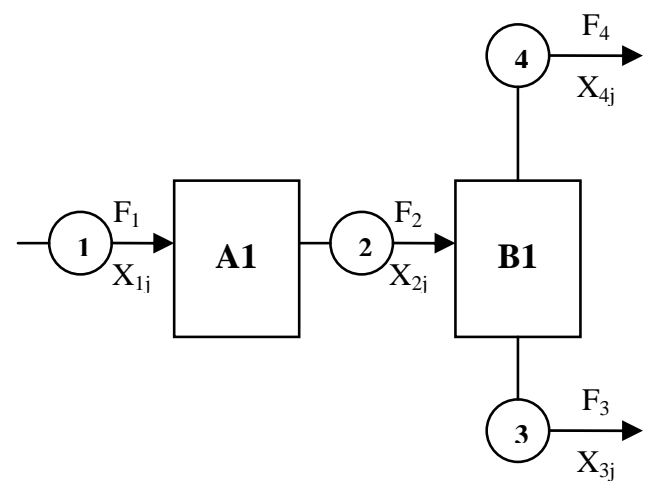

Gambar 2. Simbol pada penyusunan diagram alir proses

DAP terdiri dari peralatan atau satuan unit (unit operation) dan aliran (stream). Tiap aliran baik masuk maupun keluar peralatan ditandai dengan lingkaran yang diberi kode nomor. Pada aliran tersebut, menggambarkan karakteristik total seperti kecepatan aliran, $F_{i}$, dengan indek $i$ menunjukkan nomor aliran. Selain karakteristik total juga terdapat karakteristik komponen yang memuat informasi berdasarkan aliran dan bahan, seperti fraksi komponen, panas jenis dan lain-lain dengan simbol, $X_{i j}$, dengan indek $j$ sebagai kode nomor bahan dan $i$ menunjukkan nomor aliran. Sedangkan sebagai satuan operasi (peralatan, Unit Operation) diberi kode gabungan huruf dan nomor, misalkan $\mathbf{A 1}$ atau B1.

Pada metoda algoritma modular ini, susunan dari karakteristik komponen ditandai dengan indek $i, j$ dapat disusun dalam bentuk matrik (dua dimensi), dengan baris $i$ menyatakan nomor aliran dan kolom $j$ sebagai nomor bahan. Oleh karenanya akan lebih baik apabila digunakan perangkat lunak yang berbasis matrik, karena proses penyelesaiannya akan lebih cepat. Berdasarkan hal tersebut, perangkat lunak Scilab lebih tepat digunakan dalam penyusunan program ini dengan pertimbangan Scilab merupakan program berbasis matrik sebagaimana perangkat lunak matlab ${ }^{\circledR}$ (Rietsch, 2002), selain itu Scilab merupakan perangkat lunak dengan bebas biaya lisensi (Chandler and Roberts, 2002).

\section{METODE PENELITIAN}

Kerangka pikir untuk membuat simulasi sistem proses berdasarkan pada Gambar 1. Secara garis besar dapat dibagi menjadi tiga bagian:

1. Masukan dari pengguna yang merupakan informasi dasar dari simulasi: 
a. Semua bahan pada sistem proses serta kondisi awal sistem proses

b. Susunan dari Diagram Alir Proses (DAP).

2. "Algoritma modular" sebagai bagian dari penyelesaian simulasi sistem proses.

3. Keluaran sebagai hasil simulasi dalam bentuk tabel atau grafik.

Sebagai studi kasus, disusun Sistem Proses dengan daur ulang yang meliputi sebuah peralatan utama yaitu reaktor stokhiometri dan dua buah peralatan sebagai bagian untuk melakukan proses daur ulang (recycle) yaitu pencampur (mixer) dan pemisah (splitter). Pada proses daur ulang ditambah satu buah alat yang bersifat 'maya' sebagai bagian dari proses perhitungan, sebagaimana Gambar 3.

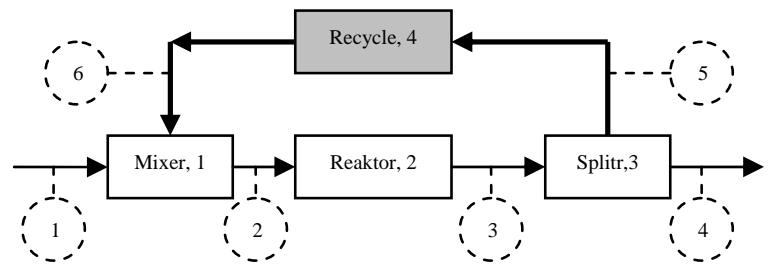

Gambar 3. Contoh Sistem Proses dengan daur ulang

Deskripsi proses sebagai gambar dari studi kasus ini adalah reaksi pembakaran metana $\left(\mathrm{CH}_{4}\right)$ dan etana $\left(\mathrm{C}_{2} \mathrm{H}_{6}\right)$ dengan udara. Diasumsikan reaksi berlangsung dengan konversi (X) per pass tetap, pada Reaktor Stokhiometri. Reaksi yang terjadi pada reaktor tersebut adalah sebagai berikut:

$\begin{array}{lll}\text { 1. } & \mathrm{CH}_{4}+2 \mathrm{O}_{2} \rightarrow \mathrm{CO}_{2}+2 \mathrm{H}_{2} \mathrm{O} & X_{1}=60 \% \\ \text { 2. } \mathrm{C}_{2} \mathrm{H}_{6}+7 / 2 \mathrm{O}_{2} \rightarrow 2 \mathrm{CO}_{2}+3 \mathrm{H}_{2} \mathrm{O} & X_{2}=80 \%\end{array}$

Sebagian dari hasil keluaran reaktor (aliran 3) dipisahkan dengan splitter (aliran 5) dikembalikan (recycle) bercampur dengan umpan segar dan dimasukkan ke dalam reaktor kembali. Sedangkan aliran keluaran lain dari splitter (aliran 4) sebagai output dari sistem. Perbandingan keluaran splitter yang di kembalikan dengan yang di keluarkan sebagai produk sebesar $R_{s}$ dengan nilai yang diasumsikan tetap. Akan dihitung neraca massa dari tiap bahan (komponen) pada semua aliran dari sistem.

Tahapan pertama, yang perlu dilakukan oleh pengguna akhir dalam menggunakan aplikasi sistem proses ini, adalah:

1. Memilih semua bahan (komponen) pada sistem proses.

2. Memilih peralatan sistem proses

Dalam pemilihan peralatan dimulai dari peralatan untuk bahan baku masuk, dengan penomoran awal pada peralatan. Pada contoh, mixer nomor alat 1 .

3. Menentukan penomoran keluar masuk aliran pada peralatan (pada Gambar 3, nomor dalam lingkaran garis putus-putus).

Pada tahap pertama, program ini menyediakan bank data dari sifat fisis bahan yang disimpan pada perangkat lunak spread sheet semacam excel, akan tetapi disini digunakan OpenOffice.org Calc (oOCalc) bersifat bebas biaya, yang disimpan ekstensi xls. Sebagai contoh, Gambar 4 merupakan tampilan bank data dari bahan (kolom 2) dari Berat Molekul (kolom 3), titik leleh (kolom 4) dan seterusnya, yang disimpan dengan nama file: DataFisbs.xls.

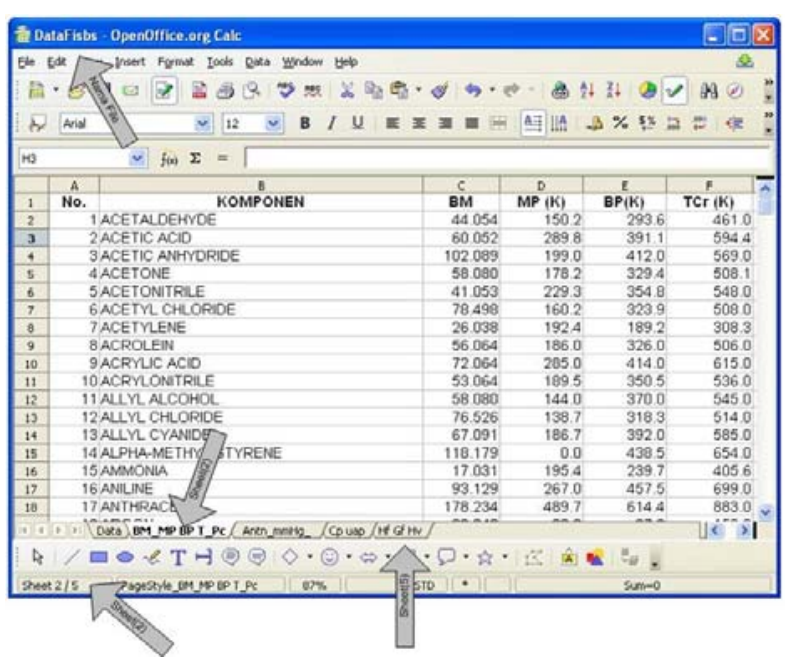

Gambar 4. Bank data dari bahan menggunakan oOcalc

Pada Gambar 4, untuk memudahkan dalam pengelolaan data-data, maka data dibedakan dalam beberapa sheet atau lembar kerja. Untuk membuka data yang dibagi dalam beberapa sheet tersebut dilakukan dengan perintah readxls. Agar program bersifat lebih interaktif dengan pengguna akhir, maka digunakan perintah "antar muka pengguna (GUI)", dalam hal ini digunakan perintah x_mdialog, x_choose, dengan hasil sebagaimana ditunjukkan pada Gambar 5, 6 dan 7.

Tabel 1. Program masukan bersifat "GUI”

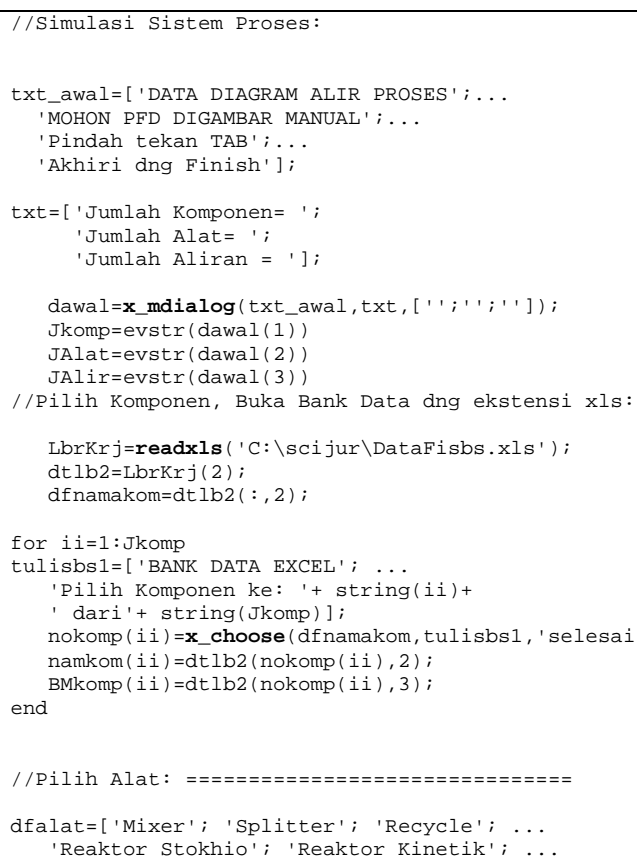




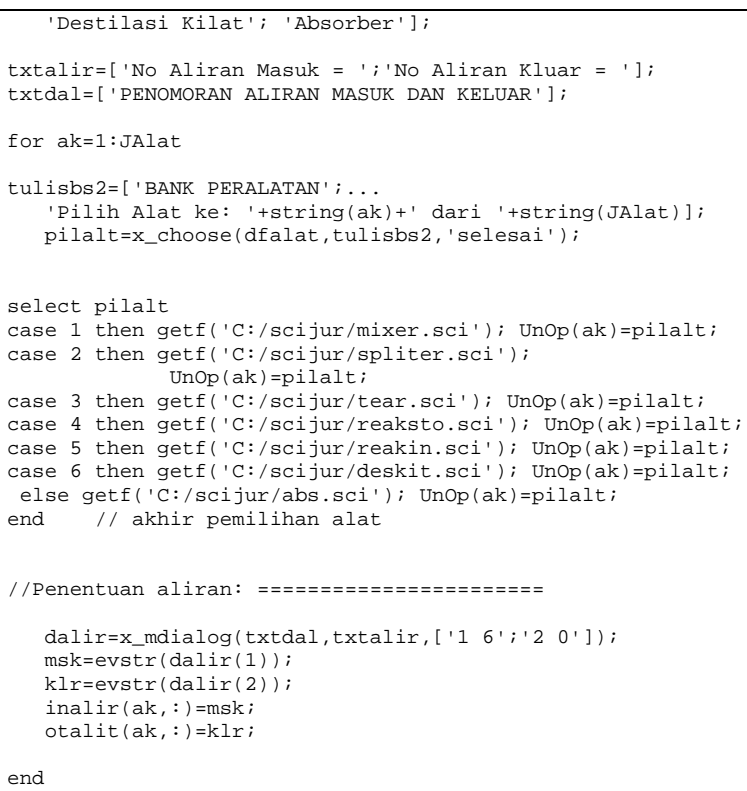

Pada Tabel 1 merupakan program utama dengan menggunakan Scilab sebagai tahap pertama dari simulasi sistem proses yang berisi tentang interaksi antara pengguna akhir dengan program berupa:

a. Penentuan jumlah komponen, jumlah alat satuan operasi dan jumlah aliran yang ada pada sistem proses. Proses interaksi antara program dengan pengguna akhir digunakan interface sebagaimana yang ditunjukkan pada Gambar 5.

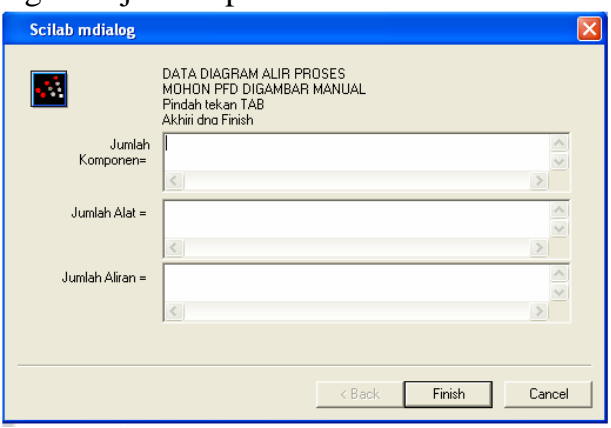

Gambar 5. Penentuan jumlah komponen, alat dan aliran dengan perintah $\mathrm{x} \_$mdialog.

b. Pemilihan semua bahan (komponen) yang terlibat dalam sistem proses, sebagai hasil eksekusi pada tahap ini dapat dilihat pada gambar 6a. Pada program ini, pada pengguna hanya mengklik bahan (komponen) yang digunakan. Pada judul terlihat proses pemilihan komponen ke 1 dari jumlah komponen total 6 berdasarkan data yang telah dimasukkan sebelumnya oleh pengguna sebagaimana Gambar 5.

c. Pemilihan peralatan berdasarkan urutan dari diagram alir proses, dengan hasil eksekusi seperti pada Gambar 6b. Jadi "Mixer” sebagai alat ke 1, "Reaktor Stokhiometri" alat ke 2, "Splitter" alat ke 3 dan "Recycle" yang bersifat maya sebagai alat ke 4. Pada judul terlihat hal yang sama seperti pada proses sebelumnya. d. Setiap kali satu alat telah dipilih, maka akan muncul jendela dialog sebagaimana yang ditunjukkan pada Gambar 7. Pada bagian ini, program meminta pengguna memasukkan nomor aliran masuk dan keluran dari alat dalam bentuk matrik dengan ukuran yang sama. Karena mixer terdiri dari dua masukkan dan satu keluaran, maka ditulis 16 untuk aliran masukkan dan 20 untuk aliran keluaran. Hal yang sama untuk selanjutnya pada reaktor masukkan 20 dan aliran keluaran 30.

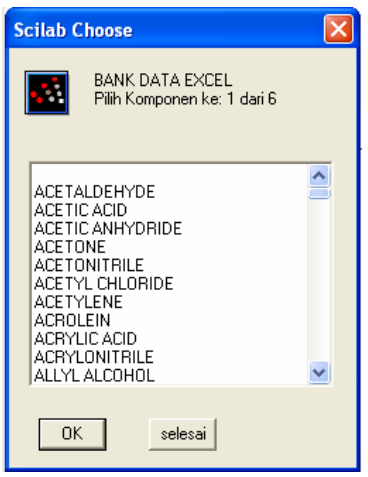

a. Komponen

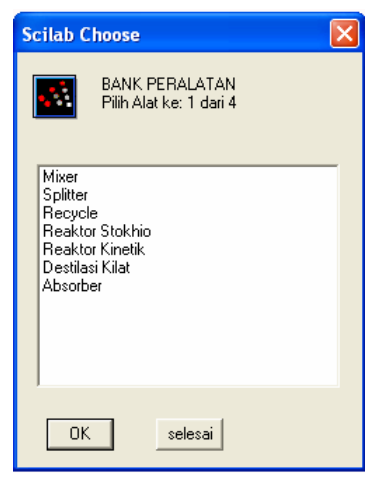

b. Peralatan
Gambar 6. Pemilihan komponen dan alat dengan perintah x_choose.

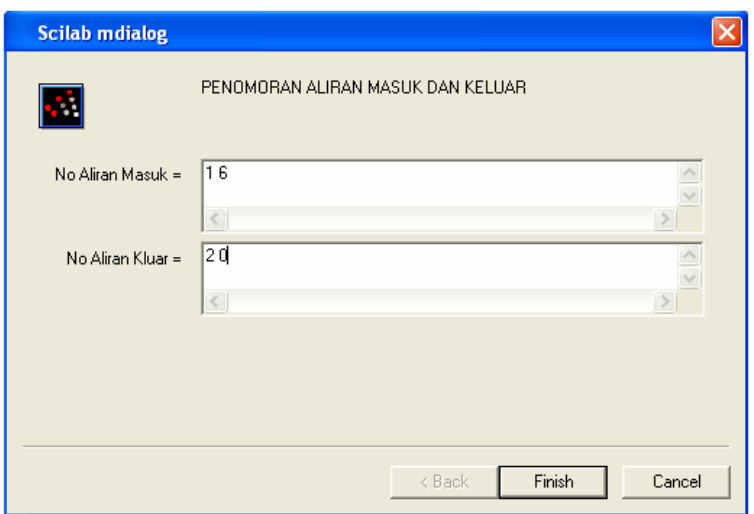

Gambar 7. Penentuan nomor aliran masuk dan keluar untuk tiap alat.

Selanjutnya, tahap kedua merupakan tahap yang dilakukan oleh program yaitu perhitungan secara modular. Arti modular, tiap alat dibuat dalam satu modul atau sub rutin berdasarkan kriteria yang telah dimasukkan oleh pengguna dan hasil perhitungan dari modul sebelumnya. Pada kasus diatas digunakan empat modul dengan sub rutin sebagaimana yang ditunjukkan pada Tabel 2 sampai dengan 5.

Pada artikel ini, hanya akan dibahas modul berdasarkan kasus diatas saja. Gambar 8 menunjukkan diagram balok dari modul mixer beserta notasi variabel masukkan dan keluaran. Semua variabel diproses dalam susunan larik (array) dalam bentuk matrik. Dalam hal ini, indek $i$ menunjukkan aliran dan indek $j$ sebagai komponen 
(bahan). Penyelesaian modul mixer berdasarkan pada persamaan berikut:

$$
\begin{aligned}
& \mathrm{Fo}_{\mathrm{i}}=\sum_{\mathrm{i}=1}^{\text {aliran }}{ }^{\mathrm{in}} \mathrm{Fin}_{\mathrm{i}} \\
& \mathrm{Xo}_{\mathrm{i}, \mathrm{j}}=\frac{\sum \mathrm{Fin}_{\mathrm{i}} \cdot \mathrm{X}_{\mathrm{i}, \mathrm{j}}}{\mathrm{Fo}_{\mathrm{i}}}
\end{aligned}
$$

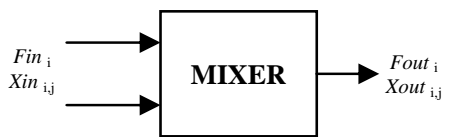

Gambar 8. Diagram balok modul mixer

Tabel 2. Modul mixer

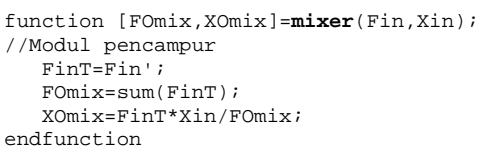

Untuk modul reaktor stokhiometri diasumsikan dengan neraca bahan sistem linear, dengan penyederhanaan:

- Konversi molar dari sejumlah reaksi paralel, NR

- Tiap reaksi $r$, didefinisikan komponen kunci, pereaksi pembatas, $l(r)$

- $\quad$ Normalisasi koefisien stoikhiometri:

$$
N_{r, k}=\frac{S_{r, k}}{S_{r, l}}
$$

Dimana:

$S_{r, k}=$ koefisien stoikhiometri untuk reaksi ke $r$ pada komponen $k$

$S_{r, l}=$ koefisien stoikhiometri komponen kunci $l$ untuk reaksi $r$.

- Dengan menggunakan konvensi

o $\quad N_{r, k}>0$, jika komponen merupakan produk

o $\quad N_{r, k}<0$, jika komponen merupakan reaktan

o $\quad N_{r, k}=0$, jika komponen merupakan inert

- Definisi fraksi konversi per pass didasarkan pada pereaksi pembatas

$$
\mathrm{M}_{\mathrm{RX}, \mathrm{k}}=\mathrm{M}_{\mathrm{IN}, \mathrm{k}}+\sum_{\mathrm{r}=1}^{\mathrm{NR}} \mathrm{N}_{\mathrm{r}, \mathrm{k}} \mathrm{X}_{\mathrm{r}} \mathrm{M}_{\mathrm{IN}, \mathrm{l}}
$$

Dimana: $X_{r}=$ konversi per pass pada reaksi ke $r$

Normalisasi koefisien stokhiometri, $N_{r, k}$ dapat dilihat Tabel 3.

Tabel 3. Koefisien stokhiometri pada reaksi 1 dan 2 dengan kode nomor komponen

\begin{tabular}{ccccccc}
\hline $\begin{array}{l}\text { No.komp, } \\
\rightarrow\end{array}$ & $\mathbf{1}$ & $\mathbf{2}$ & $\mathbf{3}$ & $\mathbf{4}$ & $\mathbf{5}$ & $\mathbf{6}$ \\
\hline$r, \downarrow$ & $\mathrm{CH}_{4}$ & $\mathrm{O}_{2}$ & $\mathrm{C}_{2} \mathrm{H}_{6}$ & $\mathrm{CO}_{2}$ & $\mathrm{H}_{2} \mathrm{O}$ & $\mathrm{N}_{2}$ \\
1 & -1 & -2 & 0 & 1 & 2 & 0 \\
2 & 0 & $-7 / 2$ & -1 & 2 & 3 & 0 \\
\hline
\end{tabular}

Persamaan untuk pereaksi pembatas dapat ditulis sebagai berikut:

$M_{R X, C H 4}=M_{I N, C H 4}-0,6 M_{I N, C H 4}=0,4 M_{I N, C H 4}$

$M_{R X, C 2 H 6}=M_{I N, C 2 H 6}-0,8 M_{I N, C 2 H 6}=0,2 M_{I N, C 2 H 6}$ (5)
Persamaan (4) dan (5) dapat ditulis dengan kode nomor komponen sebagaimana persamaan (6) dan (7).

$M_{R X, 1}=M_{I N, 1}-0,6 M_{I N, 1}=0,4 M_{I N, 1}$

$M_{R X, 3}=M_{I N, 3}-0,8 M_{I N, 3}=0,2 M_{I N, 3}$

Untuk komponen yang lain:

Komponen $\mathrm{O}_{2}$ dengan kode nomor 2:

$M_{R X, 2}=M_{I N, 2}-2(0,6) M_{I N, 1}-7 / 2(0,8) M_{I N, 3}$

Komponen $\mathrm{H}_{2} \mathrm{O}$ dengan kode nomor 5:

$M_{R X, 5}=M_{I N, 5}+2(0,6) M_{I N, 1}+3(0,8) M_{I N, 3}$

Komponen $\mathrm{CO}_{2}$ dengan kode nomor 4:

$M_{R X, 4}=M_{I N, 4}+(0,6) M_{I N, 1}+2(0,8) M_{I N, 3}$

Sedangkan modul untuk reaktor stokhiometri dapat dilihat pada Tabel 4 berikut.

Tabel 4. Modul reaktor stokhiometri

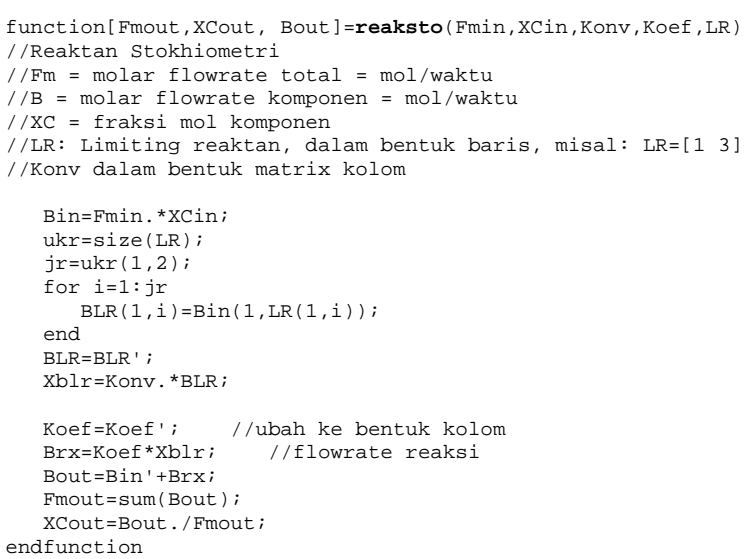

Modul splitter hampir sama dengan modul mixer, hanya pada mixer aliran masuk lebih dari satu menjadi satu, sedangkan pada splitter aliran masuk satu menjadi lebih dari satu (banyak). Sub rutin untuk splitter dapat dilihat pada Tabel 5.

Tabel 5. Modul splitter

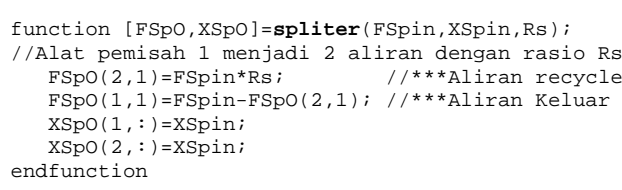

Modul recycle dianggap bagian dari alat yang bersifat abstrak atau maya. Pada bagian ini disebut juga dengan tear.

Tabel 6. Modul recycle

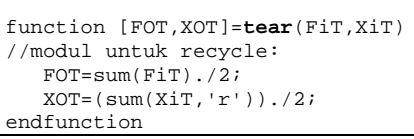


Proses perhitungan pada modul tear untuk proses recycle dengan metoda bagi dua, sebagaimana yang ditunjukkan pada Tabel 6.

\section{HASIL DAN PEMBAHASAN}

Untuk sistem proses dengan recycle, proses penyelesaiannya secara iterasi. Pada Tabel 7 merupakan tampilan untuk tiap alat dalam bentuk matrik ukuran $6 \mathrm{x}$ 6 sebagai fraksi mol komponen (bahan). Kolom dari 1 sampai 6 merupakan komponen dari bahan dengan urutan sebagaimana yang tabel konversi diatas. Sedangkan baris menunjukkan aliran dari 1 sampai dengan aliran 6. Tabel 7 merupakan proses iterasi tahap pertama, sebagaimana pada Mixer terlihat nilai yang terisi hanya pada aliran 1 dan aliran 2, hal ini disebabkan pada saat itu nilai yang terhitung pada aliran 1 sebagai umpan (masukkan awal) dari sistem dan aliran 2 sebagai hasil penjumlahan dari Mixer. Pada aliran 6 keluaran dari tear atau masukkan untuk mixer masih dianggap nol.

Tabel 7. Hasil eksekusi sistem proses secara bertahap

\begin{tabular}{|c|c|c|c|c|c|}
\hline Mixer & - Unop $=1$ & - Fraksi & mol & & \\
\hline 0.038 & 0.231 & 0.038 & 0.000 & 0.000 & 0.923 \\
\hline 0.038 & 0.231 & 0.038 & 0.000 & 0.000 & 0.923 \\
\hline 0.000 & 0.000 & 0.000 & 0.000 & 0.000 & 0.000 \\
\hline 0.000 & 0.000 & 0.000 & 0.000 & 0.000 & 0.000 \\
\hline 0.000 & 0.000 & 0.000 & 0.000 & 0.000 & 0.000 \\
\hline $0.00 \odot$ & $\odot . \odot \odot \odot$ & $\odot . \odot \odot \odot$ & 0.000 & $0.00 \odot$ & 0.000 \\
\hline \multicolumn{6}{|c|}{ Reaktor - Unop $=2$ - Fraksi mol } \\
\hline 0.038 & 0.231 & 0.038 & 0.000 & 0.000 & 0.923 \\
\hline 0.038 & 0.231 & 0.038 & 0.000 & 0.000 & 0.923 \\
\hline 0.012 & 0.062 & 0.006 & 0.068 & 0.111 & 0.741 \\
\hline 0.000 & 0.000 & 0.000 & 0.000 & 0.000 & 0.000 \\
\hline 0.000 & 0.000 & 0.000 & 0.000 & 0.000 & 0.000 \\
\hline 0.000 & 0.000 & 0.000 & 0.000 & 0.000 & 0.000 \\
\hline \multicolumn{6}{|c|}{ Splitter - Unop $=3-$ Fraksi mol } \\
\hline 0.038 & 0.231 & 0.038 & 0.000 & 0.000 & 0.923 \\
\hline 0.038 & 0.231 & 0.038 & 0.000 & 0.000 & 0.923 \\
\hline 0.012 & 0.062 & 0.006 & 0.068 & 0.111 & 0.741 \\
\hline 0.012 & 0.062 & 0.006 & 0.068 & 0.111 & 0.741 \\
\hline 0.012 & 0.062 & 0.006 & 0.068 & 0.111 & 0.741 \\
\hline 0.000 & 0.000 & 0.000 & 0.000 & 0.000 & 0.000 \\
\hline \multicolumn{6}{|c|}{ Tear - Unop-maya=4 - Fraksi mol } \\
\hline 0.038 & 0.231 & 0.038 & 0.000 & 0.000 & 0.923 \\
\hline 0.038 & 0.231 & 0.038 & 0.000 & 0.000 & 0.923 \\
\hline 0.012 & 0.062 & 0.006 & 0.068 & 0.111 & 0.741 \\
\hline 0.012 & 0.062 & 0.006 & 0.068 & 0.111 & 0.741 \\
\hline 0.012 & 0.062 & 0.006 & 0.068 & 0.111 & 0.741 \\
\hline 0.006 & 0.031 & 0.003 & 0.034 & 0.056 & 0.370 \\
\hline
\end{tabular}

Selanjutnya pada alat kedua, reaktor baris ke tiga terisi, yang merupakan hasil reaksi oksidasi dari gas metana dan etana sebagaimana yang ditunjukkan deskripsi proses. Pada baris ke tiga semua komponen terisi nilainya. Baris ke empat sampat ke enam masih kosong, karena perhitungan belum sampai pada modul tersebut. Pada modul splitter, baris ke empat yang berarti aliran ke empat dan ke lima sudah terisi. Hal ini disebabkan karena proses perhitungan pada splitter sudah dieksekusi pada saat itu.

Tahap terakhir pada iterasi pertama adalah alat recycle (proses tear) dengan metoda bagi dua yaitu bagi dua antara aliran (dalam hal ini baris) ke lima dan ke enam. Hasil akhir proses bagi dua adalah baris ke enam pada Tabel 6. Pada baris tersebut terlihat bahwa nilainya masih jauh berbeda dibandingkan pada baris 3, 4 dan 5. Ketiga baris tersebut mempunyai nilai komposisi yang sama dikarenakan, peralatan splitter hanya membagi aliran tanpa merubah komposisi. Proses iterasi diatas berjalan terus hingga didapat nilai antara aliran ke lima dan ke enam sama dengan toleransi 0.0000001. Hasil akhir dari proses iterasi dapat dilihat pada Tabel 8 dengan iterasi sebanyak 49 kali. Sedangkan pada Tabel 9 merupakan hasil akhir berdasarkan neraca massa, dimana kolom pertama merupakan laju alir total (kg/jam) sedangkan kolom dua sampai dengan tujuh merupakan fraksi berat dari komponen (bahan) $\mathrm{CH}_{4}, \mathrm{O}_{2}, \mathrm{C}_{2} \mathrm{H}_{6}, \mathrm{CO}_{2}, \mathrm{H}_{2} \mathrm{O}$ dan $\mathrm{N}_{2}$.

Tabel 8. Hasil akhir iterasi

\begin{tabular}{|lllllll|}
\hline \multicolumn{7}{|c|}{ Hasil akhir iterasi dengan tol=0.0000001 sebesar 49 adalah } \\
0.038 & 0.231 & 0.038 & 0.000 & 0.000 & 0.923 & \\
0.028 & 0.168 & 0.027 & 0.026 & 0.042 & 0.859 & \\
0.010 & 0.051 & 0.005 & 0.074 & 0.121 & 0.740 & \\
0.010 & 0.051 & 0.005 & 0.074 & 0.121 & 0.740 & \\
0.010 & 0.051 & 0.005 & 0.074 & 0.121 & 0.740 & \\
0.010 & 0.051 & 0.005 & 0.074 & 0.121 & 0.740 & \\
\end{tabular}

Tabel 9. Hasil akhir iterasi berdasarkan neraca massa

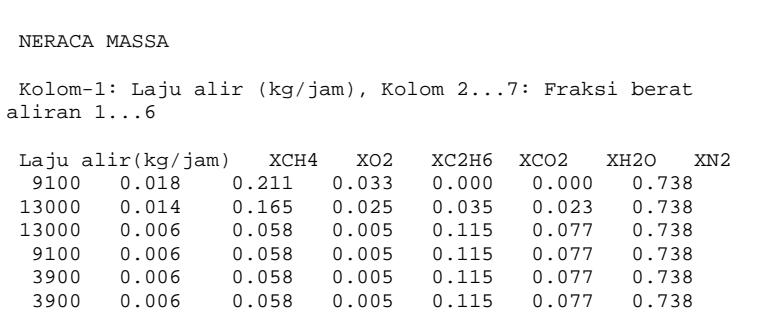

\section{KESIMPULAN}

Penerapan algoritma modular pada sistem proses dengan recycle menggunakan perangkat lunak bebas biaya memberikan hasil yang cukup baik. Penyusunan program dibuat bersifat user friendly dan umum sehingga akan memudahkan pengguna akhir.

\section{UCAPAN TERIMA KASIH}

Pada kesempatan ini, penulis mengucapkan terima kasih pada konsorsium Scilab serta Open Office yang telah mengijinkan penggunaan perangkat lunaknya.

\section{DAFTAR PUSTAKA}

Biegler, L.T., Grossmann, I.E., and Westerberg A.W., (1997), Systematic Methods of Chemical Process Design, Prentice Hall PTR.

Chandler G., Roberts S., (2002), Intoduction to Scilab, Scilab/primer.pdf)

(http://comptlsci.anu.edu.au/

Rietsch, E., (2002), An Introduction to Scilab from a Matlab User's Point of View, (http:/www.math.tuberlinde/ ehrhardt/scilab/doc/html/intro) 